\title{
Doing theology through reception studies: Towards a post- postmodern theological hermeneutics
}

\begin{abstract}
In this paper, I propose a new approach to the role of the Bible in systematic theology. I take my starting point in the contemporary clash between those who follow the Enlightenment disintegration of Scripture, and conservative attempts to do theology on the basis of Scripture as the infallible Word of God. Subsequently, I present my research project into the reception of John as a way of pursuing insights from all major stages of the history of theological hermeneutics. A deconstructive reading of pre-modern use of the Bible shows that it is much more sensitive to diverging voices in Scripture than is often assumed. Scrutinizing the reasons that pre-modern theologians have for privileging John over Paul or the other way around, brings up theological motives that become fresh material for doing theology today.
\end{abstract}

\section{DEDICATION}

This article is written in celebration of the 80th birthday of Vincent Brümmer, the 'father of the Utrecht School', among whose latest generations of students I myself number. During my undergraduate studies in Utrecht, I had the privilege of following a course he gave on the love of God. This course led to the publication of his work entitled The Model of Love (Brümmer 1993). By the time I was a graduate student, Brümmer was less active in teaching the younger students, so that I wrote no more than a single graduate paper in the philosophy of religion under his supervision, a paper on hermeneutics. Brümmer was only moderately happy with this paper, a circumstance that probably had to do with the quality of the paper, but also with something that affected the impact of Brümmer on my studies at Utrecht.

Although I was strongly attracted by the 'Brümmer school', there were two factors that shaped y particular way of being a pupil of the so-called 'Utrecht School'. One such factor is that, almost from the beginning, I was fascinated not only by philosophical theology, but also by the continental philosophical tradition in which teachers from the Catholic Theological University (KTU) were engaged: Ilse Bulhof and Bert Blans introduced me to Gadamer, Dilthey, Heidegger and Derrida, (e.g. Bulhof \& ten Kate 2000). The rather straightforward lines of reasoning produced within an analytic philosophical context, created a place within my heart for these thinkers next to the philosophical theological tradition.

A second shaping influence was my interest in the history of theology. It was Willem van Asselt who played an important role in awakening and reinforcing this interest, which had its roots in my traditional Reformed background (see Asselt et al. 2010; Wisse et al. 2010). What I sometimes missed in Brümmer's work was a sensitivity to the meandering paths that historical processes can take. It often seemed as if the complexity of history could be reduced to a set of simple concepts from which the theologian then had to choose a few in order to get rid of certain

1 Maarten Wisse teaches dogmatics and ecumenics at VU University Amsterdam and is Privatdozent in systematic theology at the Eberhard-Karls-University of Tübingen, Germany. Email: maarten.wisse@ vu.nl. 
inconsistencies in the tradition, thereby adding the finishing touches to a slightly defective but coherent story of Christianity.

Notwithstanding these two aspects, I was enormously fascinated by the philosophical theology that Brümmer and his pupils practised, and am still most grateful for having learned to use the tools of analytic philosophy in theology. Brümmer taught his students first and foremost that theology, especially systematic theology, cannot be content with a description of positions from the past, but has to say something in the present. This invited his students and gave them the confidence to engage in creative theological thought, rather than leaving them with the feeling that all those great thinkers from the past spoke the last word in theological matters. Almost from the very beginning of my studies in Utrecht, I felt attracted to this theological free spirit, although it admittedly took me some time to learn to formulate those creative ideas in such a way that others could understand and appreciate them.

The following paper testifies to my roots in and indebtedness to the Utrecht School of philosophical theology. My hope is that it will show something of an attempt to think independently, and not only to reproduce the past, but also to develop new theology from it for the future. My PhD thesis (Wisse 2003), as well as my later work on Augustine (Wisse 2011), both testify to the influence of these two aspects of my studies that accompanied my adhesion to the Utrecht School. The same holds true for the present paper. One may read it as my second graduate paper on the theme of hermeneutics, as it were, submitted to Brümmer some 18 years after the first, and reflecting much of what has happened in the time between that 1995 paper and my present theological work. I hope that my former master will appreciate it, at least more than the previous one.

\section{INTRODUCTION}

Doing systematic theology with the Bible in hand is something that nowadays cannot be undertaken without being accompanied with fierce disputes. On the one end of the spectrum, we find those who are often referred to as 'biblicists': these theologians, so it is charged, do not take any account of the results of historical criticism, and act as if the Bible forms a coherent whole from which everyone may take as it pleases him or her - at one time from Paul, at another time from John, and at yet another time from the Old Testament writings. In their view, theological claims can be substantiated from all of these writings, which together form the Word of God. On the other end of the spectrum are those who claim that every reference to the Bible bypasses the fundamentally historical and fragmentary character of the Biblical witness. Theology, so this second group argues, cannot go beyond the theology of John, of Paul, of the synoptics or of any other tradition that may be identified (cf. the interesting contribution by Smith 2011).

Mainstream systematic theology seems to move somewhere between the two ends of the spectrum. The writings of some seem to suggest that they do not consider the Bible to be all that important, and that they have a greater interest in bringing the Christian tradition in dialogue with philosophy or the sciences. ${ }^{2}$ Others understand the Bible to be crucial to the practice of systematic theology, but prefer to take account of historical critical exegesis, and thereby bring their use of the Bible in conversation with the dominant voices of historical critical exegesis or 'biblical theology' (Pannenberg 1991; Berkhof 1999; and also van den Brink \& van der Kooi 2012). Those who take a position somewhere in the middle of the spectrum experience constant

2 I have learned much during my stay in Germany (Heidelberg and Tübingen) and Belgium (KU Leuven), and, although I do not intend this as a value judgement, it is worth noting that Biblical material was hardly ever mentioned as a source for substantiating or refuting a theological argument in theological conversations. 
pressure from two sides. Conservatives are unhappy with the way mainstream theologians use the Bible because they consider it to be too 'liberal'. The Bible, they fear, is no longer the true foundation of theological discourse. It has been broken up into pieces, and, in the end, the interpreter becomes the lord over the Bible rather than that the God of the Bible is the Lord of the interpreters. On the other hand, 'liberals', biblical scholars or non-believers see the use of the Bible for constructive theology either as a residue of ancient habits that are no longer plausible today, or else, and perhaps in greater measure yet, as an ideological attempt to justify one's ideas in the name of God without regard for the Bible's human and fragmentary character.

There is an additional factor in play, namely what we could call 'postmodernism'. Applied to hermeneutical questions, the term 'postmodernism' denotes a growing conviction that the meaning of texts depends partly or completely on the context and intentions of the interpreter, rather than the meaning encoded in the text and backed up by the intentions of the author of the texts. Various models have been developed in response to this claim, falling back either on a defence of authorial discourse interpretation, or on a reappreciation of the role of the community of readers in the interpretation of Biblical texts.

In this contribution, I would like to propose a new way of looking at doing theology with the Bible. In the following section, I will revisit the problems sketched above from a historical point of view in order to bring out the key aspects and virtues of the way the Bible was used in the history of Christian theology, or at least as emerges from a 'textbook account' of the history of the way in which the Bible was used. Thereafter, I will outline my current research project on the reception of the Gospel of John as an alternative way of looking at the use of the Bible in theology, both from a historical point of view and as a new way of doing systematic theology with the Bible through the lens of reception studies.

\section{A HISTORICAL PERSPECTIVE ON THE USE OF THE BIBLE}

In this section, I will give a rough and schematic outline of the way Christians used the Bible for theological purposes. This is done with a view to the final section, in which I will sketch my own approach to the use of the Bible in my project on the reception of John. In that final section, I will try to show how my project responds to and takes up elements from all stages of the Bible's use across the history of the Christian church. My project incorporates these elements and makes them fruitful for the analysis, but still takes them to a new level.

The first crucial stage in the history of Christian use of the Bible can be labelled the premodern, pre-Reformation stage. I will count the second stage, the Reformation phase, as a part of the pre-modern stage - although it justifiably could be called early modern as well - for reasons that I will explain shortly. The pre-modern, pre-Reformation stage thus encompasses the Early Church and the Middle Ages. What characterizes the use of the Bible during this stage is, positively speaking, that both text and reader belong to one and the same "world", as Hans Frei has called it in his Eclipse of Biblical Narrative (Frei 1974:2ff). One could consider the use of the Bible during this stage as being rather "naive" in the sense that later questions about the Bible as a foundation of "dogmatics" did not really enter into play yet, although various authors did at times ask questions or make remarks that would later be used for statements concerning the precise role of the Bible in theological discourse (for examples, see Fernhout 1994:86-106). In the terms of a metaphor taken from the present, one could say that using the Bible in the premodern and pre-Reformation period was like walking in a cloud, a word cloud in which all kinds of Bible verses floated around and passed by. The believer moves around in this cloud and picks a verse that suits his or her theological claim. In this cloud, Bible verses are connected through associative networks, which in turn are linked up and determined by theological considerations. 
These considerations can be based on the literal meaning of the text, but also on a figurative reading of the text, depending on the occasion, theological context or authoritative tradition.

For example, when Augustine theologizes about seeing God, Matthew 5:8 ("Blessed are the pure in heart, ...") is always in the background as a Bible verse, and on the basis of his conviction that purity of heart is impossible in this life, Augustine will often move to another much loved Bible verse to speak about how we live in faith on earth: "For now we see in a mirror dimly, but then face to face, quoting Paul in 1 Corinthians 13:12. Although in this example no explicitly figurative interpretation is in play, it is evident that the way in which Augustine brings the two Bible verses together is rather creative and is motivated by specific theological presuppositions. In the Middle Ages, this associative use of the Bible came to be reinforced by the treatment of Bible verses as an anthology of verses which were taken out of their proximate or more remote biblical context. Bible verses functioned as orientation points within a web of practices (liturgy!), traditions and thoughts without a formal structure explaining why they needed to be used in this way.

Of course, in the context of certain doctrinal controversies, specific verses can be hotly disputed, and specific interpretations may begin to function as a watershed for determining one's orthodox status. If a particular Bible passage is not in dispute, its interpretation will show itself to be rather malleable. However, the more the verses are subject to controversy, the more they will be pinned down to a specific meaning that is then also explicitly related to the intention of the human or divine author of the text. Augustine once again represents a good example in this regard because he can be at once very associative in his Bible interpretation, but also extremely strict in his reading of Paul in the context of the issue of grace, to mention only one example (in both the early Ad Simplicianum, as well as the anti-Pelagian Enchiridion). While he often appears to show little interest in the intention of the human Biblical authors, in the context of the Pelagian controversy he places a heavy emphasis on Paul's intentions in writing his letters and suggests that these intentions alone can function as the criterion for interpreting him in the present.

The free-floating way in which the Bible was used before the Reformation also means that, although the Bible is often said to be infallible, it does not really function as an infallible basis for theology as it does indeed begin to do in the days of the Reformation. Augustine, for example, freely uses the regula fidei - i.e. essentially the Nicene creed - in his Doctrina christiana as a criterion for the correct reading of the Bible (Augustine 1996:177 [III, 10, 14]; for the way in which Augustine situates the reading of Scripture within the community of faith, see Wischmeyer 2007). In the Middle Ages, Scripture is certainly at the heart of liturgy, spirituality and theology, but at the same time, it had its place among the various other authorities that were at the disposal of theologians.

The most important change in this regard occurred in the Reformation, where the authority and use of Scripture became an explicit and key theme in a theological controversy (for a broader discussion, see Wisse 2013a; Wisse \& Meijer 2013). This central role in the Reformation controversy is accompanied by a new way of reading texts in general, as well as a literary revolution related to an upcoming urban middle class and the discovery of book printing techniques. The idea arises that texts should be read in their original languages so as to enable one to come nearer to their original meaning. Not only for the Reformers Luther and Calvin, but already for Erasmus, the attempt to arrive at the original text and the original meaning of the texts is a deeply theological undertaking. Erasmus sees it as nothing less than the way to approach the God who speaks in the midst of a Church that has become addicted to all sorts of external practices which have nothing to do with the Spirit and will of God (Augustine 1986:9093). For biblical humanism, the study of Greek and Hebrew does not mean the secularisation of 
theology, but rather a theology oriented to discovering God in the study of the languages. Back to what God intended faith and theology to be!

Nevertheless, amidst the conflict between identities that the Reformation movement represented, the appeal to Scripture was also an attempt to establish Church and theology on new foundations. Sacra scriptura sui interpres was an attempt to free the reading of Scripture from external authority and to bind the use of the Bible to the intentions of both the human as well as the divine author - at least, this was how things were perceived in the controversy between defenders of the old and the new faith (François 2006). Still, it was an attempt to liberate the reading of Scripture, and, depending on how you look at it, the attempt was indeed successful. Nevertheless, the context in which the attempt was made, limited the scope of the sola Scriptura project. In the mainstream Reformations, the use of the Bible remained within the confessional boundaries of Nicene orthodoxy. Early in the Reformation, beginning already with the decades of the 1520s and 1530s, various radical Reformers admitted that a theology solely based on the Bible is impossible, because the Bible cannot bear that burden due to its internal inconsistencies (Hayden-Roy 1994:11-17). The early Luther, for example, acknowledges this when he speaks about the best books in the New Testament. In fact, one might defend the thesis that Luther never defended the notion of the Bible as the basis of the Christian faith, since he spoke of Christ, the living Word, as the centre of theology rather than a dead letter as a formal criterion (Kooiman 1977:152-161). Also noteworthy is that Scripture does not appear anywhere in the early Lutheran creedal statements, or in Melanchthon's Loci communes. Only in seventeenth-century Lutheran orthodoxy do we encounter the development of something like a locus de Sacra Scriptura. If this is correct (more or less contra Muller 2003:65-69), it is the Reformed/Calvinist Reformation alone that develops the notion of Scripture as a formal basis for doing theology. Over the course of seventeenth-century Reformed Orthodoxy, this idea is increasingly formalised and attempts are made to prove that the Bible is a coherent basis for doing theology (Muller 2003:94-103).

However, it was in the course of this same seventeenth century that the first traces of a third stage in the use of Scripture appeared on the scene, as perhaps most clearly illustrated in Baruch de Spinoza's Tractatus theologico-politicus (1670:VII-VIII). One of the key characteristics of the modern use of the Bible is the way it broke the Scriptures up into scattered pieces. No longer could one read John through the lens of the synoptics or of Paul, nor could one accept Moses to have been the author of the Pentateuch. Consequently, the attempt to construct a true theology on the foundation of a unified Bible shipwrecked on the rocks of criticism as well. If what John says is different from what Paul says, and if what they have to say can only be understood in terms of what they mean within their original context, there is hardly any reason why systematic theology should be done on the basis of Scripture anymore. The only remaining possibility is to write a theology of John, of Paul or of Mark. Starting with Gabler's famous inaugural lecture of 1787 (Sandys-Wunsch \& Eldredge 1980), biblical theology came on the scene to provide a sound historical account of themes that run through the Bible, but it was not intended to make a normative contribution to Christian faith. Dogmatics ended up as either an ordered formulation of what Christians believe, or else a rational philosophical reconstruction of theology in secular terms. Since modernity, systematic theologians who use the Bible connect to different strands in biblical scholarship, and attempt to navigate between the Scylla of a naïve use of Scripture as practiced in the 'pre-critical' era and the Charybdis of the total impasse that may follow from the consistent recognition of a variety of voices heard in the Bible.

When the case for a theological use of the Bible already found itself under great pressure in modernity because the text had been broken up into scattered parts, the a final blow was struck in the postmodern stage of the use of Scripture. The postmodern critique attacks not the biblical 
text, but the reader of that text (for the theological use of Scripture, Kelsey 1975 is an excellent example). Whereas the modern approach to the Bible still presumed that one can know what the various biblical authors mean, a postmodern approach questions the possibility of interpretation altogether. Is there actually such a thing as an intention, or is there no more than a flow of texts interpreting one another in an endless play of signs? (For an extensive discussion and critique, see Vanhoozer 1998)

\section{A PROJECT ON THE RECEPTION OF THE GOSPEL OF JOHN}

The end of the previous section brought us to the double crisis in which the use of the Bible in systematic theology now finds itself, so that we must now consider how an attempt can be made to overcome that crisis. Upon assuming a post in dogmatics at VU University Amsterdam in 2009 and completing a monograph on Augustine's doctrine of the Trinity in conversation with contemporary theology in 2011 (Wisse 2011), I have started on a project on the reception of the Gospel of John in the history of theology (cf. http://receptionofjohn.blogspot.nl). The motive for this new project was not without an explicit connection to my project on Augustine's trinitarian theology. In my research on Augustine, I was repeatedly confronted with the fact that Augustine defends some form of 'natural theology'. Of course this 'natural theology' is not to be equated directly with what has been understood by this term since the attacks of Karl Barth, and yet there is in Augustine something like a natural theology that one will not find in most contemporary Christian systematic theology. Barth was the father of a type of systematic theology whose underlying intention it was to think through the whole of Christian theology in terms of revealed theology, in terms of God's revelation in Christ. The shape of Augustine's theology, in contrast, was determined by a duality between a natural capability of knowing God on the one hand, and the restoration of that capability through faith in Christ on the other (Wisse 2011:108-148; cf. e.g. Gibson 2009).

A conference in Hoeven, organized by NOSTER (http://www.noster.org) in 2008, where Adele Reinhartz spoke on the Gospel of John from a Jewish perspective (cf. Reinhartz 2002), made me realize that what I had begun to dislike in Barth, was not present only in Barth, but already in the Bible, namely in John. Allowing for some degree of overstatement, I can still say that it became clear to me that if any Gospel can be cited in support of an exclusively Christocentric theology, it is the Gospel of John. When Barth rejects natural theology and discusses the Barmen Declaration in Church Dogmatics II/1, he gives a place of prominence to John 14:6: "I am the Way, the Truth and the Life." (Barth 1975:II/1, 175-178; for a historical deconstruction, see Wengst 1985). This realization led to the birth of my current project on John. The students' interest was quickly awakened by this project, since it combined theology with the Reformed intuition and background that most of them shared: theology should be done on the basis of the Bible. What was more natural to them than to study the reception of the Bible in their favourite theologians? Calvin, Kohlbrugge, Luther, Athanasius, Barth, Ratzinger and others were examined for the way in which they receive the Gospel of John.

Practically, the research works as follows. For systematic theological works, we begin to explore where the authors use the Gospel of John, and which verses they use and do not use (for an example, see Wisse 2012). We create a database in which the references to John are listed. Subsequently, we study these databases in more detail to see what the theologian's favourite verses are, where these citations occur, and for which verses the thinker appears to show little or no interest. On this basis, we ask the question how each theologian's reception of John relates to his or her theology. What reasons do they have for their favourite verse(s), and why do they have an interest in ignoring others? Another approach takes its starting point in commentaries 
or series of sermons on John, and studies how the theology of specific authors is interrelated with their interpretation of John, often in comparison with others.

The emphasis in my own research is on the reception of John in Augustine (Wisse \& Dupont 2013), although it is increasingly extending to the period of the Reformation as well. To give one example from Augustine, in sermo 141 he preaches on John 14:6: "I am the Way, the Truth and the Life." It is fascinating to see how it is as if Augustine had read Barth's Church Dogmatics. Immediately after he introduces the theme of the sermon, he distances himself from John by saying:

You heard, among other things, when the gospel was read, what the Lord Jesus said: I am the way and the truth and the life (Jn 14:6). Everybody yearns for truth and life; but not everybody finds the way. That God is a kind of eternal life, unchangeable, intelligible, intelligent, wise, bestowing wisdom, this quite a number of philosophers even of this world have been able to see. The truth as something fixed, stable, unalterable, in which are to be found all the formulae of all created things, this they were certainly able to see, but from a long way off; they could see it, but from a position of error; and therefore they did not find the way by which they could reach so great, so inexpressible, so completely satisfying a possession. (Augustine 1992:410)

From John 14:6, Augustine then moves to Romans 1 so as to expand on what the pagans may know about God, returning to John 14:6 only at the end of the sermon. In this way it becomes clear how Augustine, noticing that John 14:6 could be read in the 'Barthian' sense, adapts the potentially problematic meaning of this text by bypassing that possibility and reading John through the eyes Paul. Sermon 229G provides us with another example where Augustine tempers the strong implications of 14:9 ("Whoever has seen me has also seen the Father") through the lens of the hymn in Paul's letter to the Philippians, which in turn is read through the filter of a two-nature Christology (Augustine 1993:291).

In the Reformation, it is not only the questions of Christological exclusivism that bear interesting results. The Johannine prologue can be construed in the theology of the Reformation as an indicator that makes visible the lines that divide the various streams within the Protestant camp from each other (Wisse 2013b). The tension between a universal presence of Christ in the whole world on the one hand, and a particular presence of Christ to (predestined) believers alone on the other, marks the varying emphases that interpreters put on the different verses of the Johannine prologue. Universalists avant la lettre like Michael Servet or Sebastian Franck follow Erasmus in numbering 1:4 and 1:9 (the light enlightening every human being) among their favourite verses, while they conversely downplay 1:5 or 1:13 which speak about the darkness not comprehending the light or about birth from God being necessary to faith in Christ. The latter, however, are among the favourite verses of such Reformers as Bucer and Calvin, and, to a lesser extent, Luther. To mention only one other example: whereas Bucer and Calvin take pains to disarm the radical potential of 1:14 by reading 'The Word became flesh' as 'The Word assumed flesh' together with the Augustinian tradition, radical Reformers such as the Anabaptists, Servet and Franck maintain a robust reading of this verse and build their more radical or universal view of salvation on it.

\section{DOING THEOLOGY THROUGH RECEPTION STUDIES}

Now that we have seen something of the shape of the project, it is appropriate to consider how it relates to the 'textbook' account of the use of the Bible as outlined above and how it can be of help for doing constructive theology with the Bible today. My proposal is to take up elements from all key stages of the Bible's use in the history of Christianity and bring them together in a 
new way. Many of the sub-projects that have already been carried out deal with the pre-modern use of the Bible. Authors such as Augustine or Athanasius seemingly do not care whether a text comes from John or from Matthew. Even Reformation theologians, in spite of their greater sensitivity to the differences between the Biblical authors, see the whole of the Bible and especially the New Testament as the authoritative Word of God. If these theologians were to be asked for their formal view of the Bible, they would reply that all the writings contained in it are the Word of God.

On the whole, those who accept the modern fragmentation of the Bible discard such theology as no longer useful for constructive theology. In order to overcome this impasse, I propose to take an element from the postmodern stage, and to approach pre-modern authors not so much through their formal affirmation of the authority of the Bible, as from a deconstructive hermeneutics of suspicion. Rather than looking at what they say, we look at what they do, and what they do turns out to be quite different from what they say.

Rather than leaving it at this deconstruction, however, we will continue with a positive appreciation of what the pre-modern authors do. In this attempt, we take up elements both from the Reformation and from the modern stage of the use of the Bible. Notwithstanding the claims of the pre-modern authors themselves to the contrary, we approach their use of the Bible from a modern frame of reference, that is, on the basis of the assumption that different biblical authors have different views and intentions, and that even within a single book, such as the Gospel of John, one can perceive tensions and favour certain strands in the biblical traditions over others according to their own cultural and theological contexts and convictions. We thus look at pre-modern authors through this modern lens, and we find that they were in fact much more sensitive to modern insights than modern biblical scholarship has presumed. When we read pre-modern authors deconstructively, it emerges that they in fact do not believe that everything in the Bible is true! On the contrary, quite often when they prefer Paul over John or vice versa, they play down the force of the one through an appeal to the other in much the same way as modern or postmodern authors would do with various competing Biblical traditions.

When pre-modern theologians are considered apart from the instrument of a deconstructionist reading, it appears as if they never put their cards on the table regarding their motives for privileging certain Biblical texts or traditions over others. Formally they never admit to a preference for one text or tradition, although such a preference can be inferred from their interest in allegorizing certain texts. What pre-modern theologians say, is not: "Look, in this passage I read John through Paul because I am in favour of natural theology." What they (for the most part) say or just do, is: "Look, this is the only true reading of the text; this is the intention of the Holy Spirit." What makes this practice so unfortunate is that the pre-modern authors thereby hide motives that from our modern or postmodern frame of reference are not bad motives at all. Because of their formal view of Scripture, pre-modern theologians do not allow themselves to be open about their motives for not accepting John 1:14, for example. Our deconstructive analysis of their Bible use in connection with the shape of their theology, however, allows us to discover why they implicitly do criticize or downplay John 1:14 - as when a radical reading of this verse implies that human beings can become God as radically as God became a human being. For these same pre-modern thinkers, such a reading comes down to an idolizing of human beings that contravenes a key text in the Old Testament, namely the Decalogue.

At this point, the constructive use of the deconstructive methodology becomes visible. Our deconstructive approach to pre-modern authors helps us to turn their motives into fresh material for theological discussion and systematic-theological reflection. The differences between the various Reformation readings of the Johannine prologue all of a sudden present us with a set of key theological options, with profound soteriological or ecclesiological implications for 
today: a radical humanism in which neither church nor baptism are necessary (e.g. Servet and Franck), or a radical understanding of particular salvation and baptism in which believers receive eschatological bliss already in this life (e.g. Anabaptists). This fresh material therefore brings systematic theological reflection into a close relationship with both Scripture and tradition, where theological reflection breathes Biblical notions and traditions, brings them into collision with each other, counts their virtues and shortcomings, but constantly opens itself to the way in which the theological tradition appropriated these texts and traditions, bringing out the basic life options that are embedded in these traditions.

In this respect, although we approach pre-modern authors through a deconstructive method, we are able to moving beyond postmodern ways of reading as well. We do admit that readers have a decisive role in interpreting their authoritative traditions, but we do not admit that each theological interpretation of an authoritative text is as arbitrary as any other. In that sense, we take up pre-modern and modern views of interpretation, and reintroduce them within a postmodern frame of reference (Wisse 2003:146-157, 166-175).

An additional virtue of this approach is that it introduces a new relationship between systematic theology and historical scholarship. As the brief overview above has indicated, the modern approach to the Bible as a fragmented, systematic theology became increasingly alienated from and counterposed to historical methodology because it was supposed to speak normatively, but from a modern frame of reference could do so only by compromising the standards of historical research. Most of the research in the project on the reception of the Gospel of John has its place in the history of ideas and examines the use of the fourth Gospel through quantitative and qualitative analysis of texts, much in line with historical scholarship. Systematic-theological reflection is not alien to or distanced from it, but embedded in the research as the exploration of the way in which thinkers from the past confronted the challenges of their context through the reading of the Bible (cf. Wisse 2009).

Of course, the approach proposed above has consequences for the way in which systematic theology is done as well. In the end, it does not lead to a type of systematic theology in which a closed logical system is formulated. Rather, the function of systematic theology and its use of the Bible is to elucidate Christian 'forms of life' that interact with Biblical traditions and theological traditions, confronting believers in new contexts and situations with (established) ways of living the Christian life (Brümmer 1993:19-29). In such situations, systematic theology can offer fundamental options for bringing the current situation in conversation with the Bible and the tradition (Brümmer 1993:29-35). It can indicate where one finds these options in the Bible, where the opposite of such an option has its place in the Bible as well, why Christians in various contexts and situations opted for a particular option, and what the consequences of such options were. This then, helps contemporary Christians to situate themselves in the present, standing coram Deo, vis-à-vis Scripture, tradition, fellow Christians and themselves. ${ }^{3}$

\section{REFERENCES}

Asselt, Willem J. van et al. 2010. Introduction to Reformed Scholasticism. Grand Rapids: Reformation Heritage Books.

Augustijn, Cornelis 1986. Erasmus. Baarn: Ambo.

Augustine 1993. Sermons (184-229Z) on the Old Testament. Brooklyn, NY: New City Press.

Augustine 1992. Sermons (94A-147A) on the Old Testament. Brooklyn, NY: New City Press.

Augustine 1996. Teaching Christianity. Brooklyn, NY: New City Press.

Barth, Karl 1975. Church dogmatics. Edinburgh: T. \& T. Clark.

Berkhof, H. 1999. Christian Faith: An Introduction to the Study of the Faith. Eugene, Or.: Wipf and Stock.

3 I would like to thank dr. Albert Gootjes for improving my English. 
van den Brink, Gijsbert \& van der Kooi, Kees 2012. Christelijke dogmatiek: een inleiding. Zoetermeer: Boekencentrum.

Brümmer, Vincent 1993. The Model of Love: A Study in Philosophical Theology. Cambridge: Cambridge University Press.

Bulhof, Ilse Nina \& ten Kate, Laurens (Eds.) 2000. Flight of the gods philosophical perspectives on negative theology. New York: Fordham University Press.

Fernhout, Rein 1994. Canonical Texts: Bearers of Absolute Authority: Bible, Koran, Veda, Tipitaka: A Phenomenological Study. Amsterdam; Atlanta, Ga.: Rodopi.

François, Wim 2006. The Louvain Theologian John Driedo versus the German Reformer Martin Luther: And Who Could Impose Their Truth. In L. Boeve, M. Lamberigts, \& T. Merrigan, eds. Theology and the Quest for Truth. BETL. Leuven: Peeters, 31-60.

Frei, Hans W. 1974. The Eclipse of Biblical Narrative; A Study in Eighteenth and Nineteenth Century Hermeneutics. New Haven: Yale University Press.

Gibson, David 2009. Reading the Decree: Exegesis, Election and Christology in Calvin and Barth. Continuum. Hayden-Roy, Patrick Marshall 1994. The Inner Word and the Outer World: A Biography of Sebastian Franck. New York: Peter Lang.

Kelsey, David H. 1975. The Uses of Scripture in Recent Theology. Philadelphia: Fortress Press.

Kooiman, W.J. 1977. Luther en de Bijbel. 3rd ed. Baarn: Ten Have.

Muller, Richard A. 2003. Post-Reformation Reformed Dogmatics. Vol. 2, Holy Scripture: The Cognitive Foundation of Theology., Grand Rapids: Baker Academic.

Pannenberg, Wolfhart 1991. Systematic theology. Grand Rapids, Mich.: Eerdmans.

Reinhartz, Adele 2002. Befriending the Beloved Disciple: A Jewish Reading of the Gospel of John. London: Continuum.

Sandys-Wunsch, John \& Eldredge, Laurence 1980. J.P. Gabler and the Distinction between Biblical and Dogmatic Theology: Translation, Commentary, and Discussions of his Originality. Scottish Journal of Theology 33, 133-158.

Smith, Christian 2011. The Bible Made Impossible: Why Biblicism Is Not a Truly Evangelical Reading of Scripture. Brazos Press.

Spinoza, Baruch de 1670. Tractatus theologico-politicus. Hamburg. http://spinozaetnous.org/wiki/ Tractatus_theologico-politicus [Visited at 2012-10-22].

Vanhoozer, Kevin J. 1998. Is there a Meaning in this Text? The Bible, the Reader, and the Morality of Literary Knowledge. Grand Rapids, Mich.: Zondervan.

Wengst, Klaus 1985. Der Beitrag der neutestamentlichen Zitate zum Verständnis der Barmer Theologischen Erklärung. Theologische Zeitschrift 41, 3, 295-316.

Wischmeyer, Wolfgang 2007. Von Menschen für Menschen. Augustins Schrift de Doctrina Christiana, die hermeneutischen Positionierungen des Prologs. In H. de Roest \& W. Wischmeyer, eds. Heiliger Text. Die identitätsbildende Funktion klassischer Texte innerhalb einer Gemeinschaft. Theologie zwischen Ost und West. Groningen: Universiteitsdrukkerij Groningen, 109-117.

Wisse, Maarten 2013a. Hermeneutics II: From 1500 to 2000 K. Pollmann, ed. The Oxford Guide to the Historical Reception of Augustine III: Individuals and Themes,642-647.

Wisse, Maarten 2003. Scripture between Identity and Creativity: A Hermeneutical Theory Building upon Four Interpretations of Job. Utrecht: Ars Disputandi. http://adss.library.uu.nl.

Wisse, Maarten 2012. The Gospel of John in the Confessio Belgica. In P. J. Tomson, ed. The Belgic Confession at 450. Analecta Bruxellensia. Maastricht: Shaker Media, 123-135.

Wisse, Maarten 2009. Towards a Theological Account of Theology: Reconceptualizing Church History and Systematic Theology. In M. Lamberigts, L. Boeve, \& T. Merrigan, eds. Orthodoxy, Process and Product. BETL. Leuven: Peeters, 351-374.

Wisse, Maarten 2011. Trinitarian Theology beyond Participation: Augustine's De Trinitate and Contemporary Theology. London: T\&T Clark International.

Wisse, Maarten 2013b. „....welches alle Menschen erleuchtet“? Die Krise der Europäischen Identität im Spiegel der frühmodernen Rezeption des Johannesprologs. Neue Zeitschrift für Systematische Theologie und Religionsphilosophie 55, forthcoming.

Wisse, Maarten \& Dupont, Anthony 2013. "Nostis qui in schola Christi eruditi estis, lacob ipsum esse Israel": Sermo 122, In lohannis euangelium tractatus 7 and the Donatist and Pelagian Controversies. 
Submitted to Zeitschrift für antikes Christentum.

Wisse, Maarten \& Meijer, Hugo 2013. Pneumatology: Tradition and Renewal. In H. J. Selderhuis, ed. Brill Companion to Reformed Orthodoxy. Leiden: Brill, forthcoming.

Wisse, Maarten, Sarot, Marcel \& Otten, Willemien (Eds.) 2010. Scholasticism Reformed: Essays in Honour of Willem J. van Asselt. Leiden:Brill.

\section{KEY WORDS}

Hermeneutics

Dogmatics

John

Reception

Modernity

Postmodernity

Scripture

Vincent Brümmer

Augustine

Reformation

\section{TREFWOORDE}

Hermeneutiek

Dogmatiek

Johannnes

Ontvangs

Moderniteit

Postmodernisme

Bybel

Vincent Brümmer

Augustinus

Reformasie 